\title{
EVALUATION OF FLORAL CHARACTERISTICS OF MELON HYBRIDS (Cucumis melo L.) IN POLLINATOR ATTRACTIVENESS ${ }^{1}$
}

\author{
LÚCIA HELENA PIEDADE KIILL ${ }^{2}$, EDSÂNGELA DE ARAÚJO FEITOZA ${ }^{3}$, \\ KÁTIA MARIA MEDEIROS DE SIQUEIRA4 ${ }^{4}$ MÁRCIA DE FÁTIMA RIBEIRO ${ }^{5}$, \\ EVA MÔNICA SARMENTO DA SILVA ${ }^{6}$
}

\begin{abstract}
Floral morphology and biology are important characteristics for plant-pollinator interactions and may influence the behavior of these agents. This study aimed to determine which floral attributes of different melon hybrids influence this interaction and, consequently, their attractiveness in simultaneous crops. The study was conducted in the region of Petrolina, State of Pernambuco (PE)/Juazeiro, State of Bahia (BA) and Mossoró, State of Rio Grande do Norte (RN), in areas with the following melon hybrids: Yellow type, Piel de Sapo, Cantaloupe and Galia. For studies on floral morphology and biology, hermaphrodites and male flowers of each hybrid were analyzed for their size and nectar chamber size, pollen and nectar production, anthesis time and flower lifespan. Floral visitors were observed simultaneously in hybrids of three types of melon, from 5:00 a.m. to 6:00 p.m., in the two study sites. Evaluations of the corolla diameter and flower height indicated that the hermaphrodite flowers were larger in size than male flowers in all types of melon investigated, in both study sites. As for nectar chamber, male flowers are larger in width, but smaller in height, compared to hermaphrodite flowers. Regarding the volume of nectar, differences were found between floral types for the hybrids evaluated, in the two study sites; the hermaphrodite flowers produced 2-7 times more nectar than male flowers in all studied hybrids. Observations of visits of Apis mellifera to areas with simultaneous flowering of the three types of melon demonstrated differences in the frequency of visits between hybrids, floral type and foraged resource. Flowers of the hybrids Piel de Sapo and Cantaloupe exhibited larger corolla diameter, larger dimensions of the nectar chamber and greater supply of resources for foraging, which could explain the higher number of visits of bees to their flowers in the sites studied. Index terms: anthesis, Cucurbitaceae, nectar, pollen, floral resources.
\end{abstract}

\section{AVALIAÇÃO DE CARACTERÍSTICAS FLORAIS DE HÍBRIDOS DE MELOEIRO (Cucumis melo L.) NA ATRATIVIDADE DE POLINIZADORES}

RESUMO - A morfologia e a biologia floral são consideradas como características importantes nas interações planta-polinizador e podem influenciar o comportamento desses agentes. O objetivo deste trabalho foi verificar quais os atributos florais de híbridos de diferentes tipos de meloeiro poderiam influenciar nessa interação e, consequentemente, em sua atratividade em cultivos simultâneos. O estudo foi realizado na região de Petrolina-PE/Juazeiro-BA e Mossoró-RN, em áreas com os híbridos de meloeiro do tipo amarelo, pele-de-sapo, cantaloupe e gália. Para o estudo da morfologia e a biologia floral, foram selecionadas flores hermafroditas e masculinas de cada híbrido, que foram avaliadas em relação às suas dimensões e da câmara nectarífera, produção de pólen e de néctar, horário de abertura e tempo de vida da flor. Os visitantes florais foram observados concomitantemente em híbridos de três tipos de meloeiro, no período das $5 \mathrm{~h}$ às $18 \mathrm{~h}$, nos dois locais de estudo. As avaliações do diâmetro da corola e da altura da flor mostraram que as flores hermafroditas apresentaram dimensões maiores que as masculinas em todos os tipos de meloeiro avaliados, em ambos os locais de estudo. Quanto à câmara nectarífera, as flores masculinas apresentaram dimensões maiores para a largura, porém menores para a altura, quando comparadas às flores hermafroditas. Para o volume do néctar, diferenças foram registradas entre os tipos florais para os híbridos avaliados nos dois locais estudados, sendo que as flores hermafroditas produziram de 2 a 7 vezes mais néctar do que as masculinas em todos os híbridos estudados. As observações da visitação de abelhas Apis mellifera em áreas com floração simultânea dos três tipos de meloeiro mostraram que houve diferenças na frequência de visitas na comparação entre os híbridos, tipo floral e o recurso forrageado. As flores dos híbridos Pele de Sapo e Cantaloupe apresentaram maior diâmetro da corola, maiores dimensões da câmara nectarífera e oferta de recurso para forrageio, os quais poderiam justificar a maior visitação de suas flores nos locais estudados.

Termos para indexação: antese, Cucurbitaceae, néctar, pólen, recurso floral.

'(Trabalho 057-15). Recebido em: 09-02-2015. Aceito para publicação em: 30-06-2015.

${ }^{2}$ Pesquisadora da Embrapa Semiárido, BR 428, Km 152, s/n, Petrolina-PE, C.P. 23, CEP 56.302-970. E-mail:lucia.kiill@embrapa.br

${ }^{3}$ Bolsista de Apoio Técnico, Funbio/Embrapa Semiárido. E-mail: edsangela feitoza@hotmail.com

${ }^{4}$ Prof . Titular da Universidade do Estado da Bahia-DTCS, Juazeiro-BA. E-mail: katiauneb@yahoo.com.br

${ }_{5}^{5}$ Pesquisadora da Embrapa Semiárido, BR 428, Km 152, s/n, Petrolina-PE, C.P. 23, CEP 56.302-970. E-mail: marcia.ribeiro@embrapa.br

${ }^{6}$ Prof $^{\mathrm{a}}$. da Universidade Federal do Vale do São Francisco. E-mail: evasarmento@yahoo.com.br 


\section{INTRODUCTION}

Melon is a fruit consumed on a large scale in Europe, the United State and Japan. Brazil ranks $11^{\text {st }}$ in the world production of that crop, considered of great importance for the country, especially for the Northeast region, generating jobs and income for the producing states (FAO, 2013).

Melon plant (Cucumis melo L.) belongs to the family Cucurbitaceae and the genus Cucumis, which is composed of 38 species (GARG et al. 2007). In general, most cultivars have male and hermaphrodite flowers, yellow in color, with five petals. The first present five stamens and a nonfunctional style surrounded by nectaries. In turn, hermaphrodite flowers have a three lobed stigma surrounded by the nectary and inferior ovary and three anthers toward the outside of the flower, preventing selfpollination (DELAPLANE; MAYER, 2005). Thus, melon depends on biotic pollinators for a successful reproduction, and the pollination services are considered essential (dependence $>90 \%$ ) for its production (KLEIN et al., 2007).

In this sense, floral morphology may be one of the most important aspects in plant-pollinator interactions, because it determines the access to nectar, pollen deposition efficiency on the bee body and acquisition of pollen by the stigma (DORADO; VÁZQUEZ, 2014).

Floral characteristics such as size and flower symmetry, production and location of floral rewards can influence pollinator behavior, both regarding its movement on the flower and the need to visit many flowers to obtain the necessary food resources. However, pollinator efficiency, especially bees, can be influenced by other factors such as attraction to flowers of the crop, fidelity of the visited species, appropriate size and behavior to take the pollen grains from the anthers and deposition on the stigma (PINHEIRO et al., 2014).

Pollination by insects, especially bees, is essential to many crops, for instance apple tree, avocado, melon, passion fruit and pear (GIANNINI et al., 2015). For melon, studies focused on pollination were developed in different countries, showing that this plant depends on Apis mellifera to ensure productivity (SOUSA et al., 2009, 2012).

Moreover, the successful pollination can be affected by the variety planted (KLEIN et al., 2007). A comparative study of melon types and varieties found that the floral morphology may have indirectly influenced the visitation pattern of $A$. mellifera to both floral types (male and hermaphrodite) of a cultivar, and between the melon hybrids Yellow type, Piel de Sapo and Cantaloupe (KIILL et al, 2011;. 2012). Considering this, this study aimed to determine which attributes of floral biology and morphology of cultivars/hybrid of melon grown in northeastern Brazil influence the plant-pollinator interaction and consequently their attractiveness.

\section{MATERIAL AND METHODS}

Study areas: This work was conducted in melon production centers of Petrolina, State of Pernambuco/Juazeiro, State of Bahia and Mossoró, State of Rio Grande do Norte, in experimental and commercial areas cultivated with melon hybrids: Yellow type, Piel de Sapo, Cantaloupe and Galia. In the first center, the observations were made in the Experimental Field of Bebedouro (09 $09^{\circ} \mathrm{S}$; $40^{\circ} 22^{\prime} \mathrm{W}$ ), which belongs to Embrapa Tropical Semi-Arid, in Petrolina, State of Pernambuco; in commercial areas of the Mandacaru Irrigation Project $\left(09^{\circ} 24^{\prime} \mathrm{S} ; 4^{\circ} 26^{\prime} \mathrm{W}\right)$, in the Irrigated Perimeter of Salitre (09 $31^{\prime}$ 'S; $\left.40^{\circ} 15^{\prime} \mathrm{W}\right)$ and in the experimental area of the University of Bahia State- UNEB (09'25'43.6”'S; 40³2'14”W), in Juazeiro, State of Bahia. In the second center in Mossoró, State of Rio Grande do Norte, the activities were performed in a commercial area $\left(43^{\circ} 22^{\prime} 14^{\prime \prime} \mathrm{W} ; 4^{\circ} 54^{\prime} 10^{\prime \prime} \mathrm{S}\right)$. Table 1 presents the types, hybrids and cultivars of melon studied in each of these regions.

Floral morphology and biology: Analysis of floral morphology was performed in 20 flowers of each floral type, in each hybrid. Male and hermaphrodite flowers (one pair per plant) were selected at random, and subsequently measured for corolla diameter $(\mathrm{mm})$ and flower height $(\mathrm{mm})$ with a digital caliper, in both floral types. For measuring the dimensions of nectar chamber of floral types of each melon studied, male $(\mathrm{n}=10)$ and hermaphrodite $(\mathrm{n}$ $=10$ ) flowers were cut lengthwise and measured for height $(\mathrm{mm})$ and width $(\mathrm{mm})$ with a digital caliper.

For comparison of floral biology, observations were made during the anthesis period, flower lifespan, stigma receptivity throughout the day, viability and number of pollen grains produced per flower and evaluation of the volume and concentration of nectar. Differences between the anthesis time and flower lifespan were evaluated in male and hermaphrodite buds, at pre-anthesis, which were marked at random $(\mathrm{n}=20)$ and observed from 04:30 a.m. to 06:00 p.m. The stigmatic receptivity was verified with hydrogen peroxide (DAFNI et al. 2005), in hermaphrodite flowers, pre-bagged, at 6:30 a.m. $(n=6), 10: 30$ a.m. $(\mathrm{n}=6), 02: 30$ p.m. $(\mathrm{n}=6)$ and 05:30 p.m. $(\mathrm{n}=6)$ Viability of pollen grains were examined by standard 
methodology, in buds at pre-anthesis in the floral types of each studied melon hybrid and estimation of pollen grains per flower was conducted according to Kearns and Inouye (1993).

To assess the volume and concentration of nectar over the day, flowers of both floral types were protected with tulle bags. The volume of nectar was evaluated according to Kearns and Inouye (1993), at 4:00 p.m. $(n=15)$. To assess the concentration of nectar, flowers of each floral type $(n=10)$ were bagged early in the morning and evaluated at 04:00 p.m., with the aid of digital refractometer Atago N1 $(0-50 \%)$.

Assumptions of normality and homoscedasticity were checked by the KolmogorovSmirnov and Lilliefors tests. Mean values were compared by Tukey's test at 5\% probability.

Visitation: Frequency and behavior of $A$. mellifera were observed only in Salitre, Juazeiro, Bahia State (melon hybrids Yellow Type, Piel de Sapo and Galia, without the addition of beehives), and in Mossoro, Rio Grande do Norte State (melon hybrids Yellow Type, Cantaloupe and Galia, with the use of beehives), where it was possible to find simultaneous crops of more than one type of melon. The observations were carried out simultaneously in hybrids/cultivars from 05:00 a.m. to 06:00 p.m., in 5 non- consecutive days, following the spraying schedule in the area. Visitation data were transformed into mean values using (number of visits +0.5 ) and analyzed by Statistica 7.0 (STATSOFT, 2004).

\section{RESULTS AND DISCUSSION}

Floral morphology: Evaluations of the corolla diameter $(\mathrm{F}=48.45, \mathrm{df}=13, \mathrm{P}<0.05)$ and the flower height ( $\mathrm{F}=245.58$; $\mathrm{df}=13 ; \mathrm{P}<0.05)$ of floral types evidenced that, independent of the study site, in all types of melon considered, the hermaphrodite flowers presented larger dimensions than the male flowers (FIGURES 1a and b), corroborating the pattern described in the literature for other types/ cultivars of melon (SIQUEIRA et al., 2011; KIILL et al., 2012; TSCHOEKE et al., 2015).

Keeping in mind that the flowers, regardless of the floral type, are usually amongst or below the leaves, this morphological difference in size puts hermaphrodite flowers in evidence, facilitating its location by the floral visitor. In addition, given the larger surface of the corolla, this characteristic could also facilitate the visualization, the approach and the landing of visitor on the hermaphrodite flower.

These morphological differences between floral types are important for this crop, because in melon plants, the production of male flowers is higher than the production of hermaphrodite flowers, with sex ratio ranging from 6-19 male flowers to 1 hermaphrodite flower (ABREU et al, 2008; KOUONOM et al., 2009; SIQUEIRA et al., 2011; TSCHOEKE et al., 2015). In this way, although the production of hermaphrodite flowers is lower, they have morphological characteristics that make them more attractive.

The visual attraction of the pollinator at long distance is one of the main mechanisms to ensure the reproductive success of plants, where primary attractions, such as color, size and shape of flowers play a key role, especially for species dependent on pollination services, such as the melon (HEIN, 2009).

As for the corolla diameter (FIGURE 1a), there were significant differences between hybrids Sancho and 10/00, both between the hermaphrodite $(\mathrm{P}<0.01)$ and male flowers $(\mathrm{P}<0.01)$, in the region of Petrolina (PE)/Juazeiro (BA). In the material evaluated in Mossoró (RN), the hermaphrodite flowers of the hybrids Goldex and Iracema presented larger corolla, differing significantly from the other hybrids, though they did not differ from each other $(P=0.29)$. Regarding the male flowers, the hybrid Iracema differed significantly from the others. For this floral type, no significant differences were detected, only between the flowers of the hybrids Goldex and Florentino $(\mathrm{P}=0.51)$.

In relation to the flower height (FIGURE 1b), the hermaphrodite flowers of hybrids Sancho and $10 / 00$ were the highest and differed significantly from flowers of the Mandacaru hybrid, although they did not differ from each other. As to male flowers, flowers of the hybrid 10/00 were the largest and significantly different from the other hybrids, which did not differ from each other. In the material of Mossoró, the hermaphrodite flowers of the hybrid Iracema were the highest and stood out over the others. For the two characteristics, the hybrid McLaren presented the lowest values.

With regard to the nectar chamber, regardless of the study site, the male flowers had larger dimensions for width $(\mathrm{F}=39.237, \mathrm{df}=134, \mathrm{P}<0.01)$, but smaller in height $(\mathrm{F}=619.441$; df $=134$, $\mathrm{P}$ $<0.01$ ) when compared with hermaphrodite flowers (FIGURE 1c and d). This difference is related to the flower structure, since in male flowers, in the absence of gynoecium, the nectar chamber forms a single cavity. For being shorter, it would facilitate access of pollinator to the floral resource. In turn, the hermaphrodite flowers, being longer, compensate this difference by providing greater nectar storage 
capacity. Moreover, in hermaphrodite flowers, nectar becomes more protected, thus selecting flower visitors with tongue length suitable to collect the resource.

Considering the nectar chamber height (FIGURE 1c), in both sites, there were no significant differences between the male flowers of the hybrids studied. With regard to hermaphrodites, the flowers of the hybrid Sancho showed the highest values in the region of Petrolina (PE)/Juazeiro (BA). For width (FIGURE 1d), the hermaphrodite flowers of the hybrids Mandacaru and Sancho presented the larger dimensions, not differing from each other. In Mossoró ( $\mathrm{RN})$, the differences between hybrids were not as pronounced, for the two floral types.

In a comparative analysis on melon hybrids in the region of Juazeiro (BA), Kiill et al. (2011, 2012) claimed that the highest visitation observed to hermaphrodite flowers may be related to the attractiveness of the pollinator. Also, the authors commented that the floral morphology may have influenced the visitation pattern of A. mellifera in studies conducted in intercropped crops. Researches in Panamá found that the duration of visits of $A$. mellifera to melon flowers was strongly related to the floral type, and the longer time recorded in visits to hermaphrodite flowers was attributed to the greater complexity of shape and structure of this floral type (HOZ, 2007).

Despite the differences in nectar chamber height found in the studied varieties of melon, hermaphrodite and male flowers presented dimensions compatible with the average length of the proboscis of $A$. mellifera $(4.81 \pm 0.40 \mathrm{~mm})$, as reported by Souza et al. (2009). Therefore, this characteristic would not be limiting to the collection of nectar by honeybees and could not explain the differences in attractiveness between the floral types and between the studied hybrids.

Floral biology: Observations of anthesis time and flower senescence (Table 2) showed that variations may occur among the flowers of the same floral type of a same hybrid/cultivar. For anthesis, there was variation from one to two hours, which may be related to the local weather conditions, since, on cloudy days, anthesis was slower than on sunny days. Range variations in anthesis times were previously detected for the hybrid Yellow Type in the region of Mossoró (RN) (ABREU et al., 2008).

Analyzing the mean values of the times observed, for most hybrids, anthesis was registered after 6:00 a.m., in both floral types, with no difference for anthesis times between male and hermaphrodite flowers, agreeing with the literature (ABREU et al., 2008; KIILL et al., 2011). The opening of the flowers early in the morning is indicative of flowers pollinated by bees; this is regarded as a leading characteristic of the melittophily syndrome (RECH et al., 2014).

Moreover, considering the floral senescence, there were also variations between types and hybrids of melon. In the studied materials in the region of Petrolina (PE)/Juazeiro (BA), it was found that the closing of flowers occurred earlier than in Mossoró, for both floral types. In general, flower lifetime ranged from nine to twelve hours, agreeing with the pattern described for other hybrids (KIILL et al., 2011).

Similar to that observed for anthesis, the weather conditions, such as temperature and relative humidity, can also interfere with floral senescence, and it was noticed that, in warmer days, this process began earlier. The literature shows that these factors can accelerate these processes in flowers of semiarid regions (TSCHOEKE et al., 2015). In the cultivation of melon using plastic cover, temperatures are higher. This fact could accelerate dehydration of flowers, making them less attractive to flower visitors.

In the evaluation of stigma receptivity over the day, there were no differences between the materials studied in the two sites, indicating that the hermaphrodite flowers are able to be pollinated throughout flower lifespan, in agreement with the observations made to other yellow hybrids (ABREU et al., 2008).

As for pollen viability, rates exceeding $80 \%$ were recorded in both floral types, in both sites, in all the studied materials, indicating that, at the anthesis time, the pollen grains were able and available for pollination. In studies with $C$. melo subsp. agrestis, there was a similar pollen viability in floral types of this melon, with no differences in reproductive success regarding the origin of pollen grains, that is, male or hermaphrodite flower (KOUONON et al., 2009). In a comparison between melon hybrids, similarities were also verified in pollen viability between the grains produced by the two floral types, but with a decrease of this viability throughout the day, with the highest rates recorded at the anthesis time (ABREU et al., 2008).

The evaluation of the number of pollen grains produced per flower demonstrated that, regardless of the materials studied in both sites, there were no significant differences between floral types of the same hybrid $(\mathrm{P}>0.05)$. Comparing the hybrids, there were also no significant differences for both floral types, for the materials analyzed in Petrolina (PE)/Juazeiro (BA). In Mossoró (RN), significant 
differences were detected for hermaphrodite flowers, comparing the Iracema with Florentino (P $=0.029)$ and with McLaren $(\mathrm{P}<0.05)$ and for male flowers (FIGURE 2a), comparing the Goldex with Florentino $(\mathrm{P}=0.02)$ and with McLaren $(\mathrm{P}=0.01)$. Thus, although the male flowers present five anthers and hermaphrodite flowers, only three, the supply of this resource by the floral types is apparently similar, confirming that seen in flowers of C. melo subsp. agrestis (DJÈ et al., 2006)

Considering the volume of nectar, significant differences were recorded between floral types for both hybrids studied in Petrolina (PE)/Juazeiro (BA) $(\mathrm{F}=135.846, \mathrm{df}=104, \mathrm{P}<0.01)$, and in Mossoró $(\mathrm{F}=84.136 ; \mathrm{df}=88 ; \mathrm{P}<0.01)$. In all the studied hybrids, the hermaphrodite flowers produced 2 to 7 times more nectar than the male flowers, and this difference was more expressive for Mandacaru and McLaren (FIGURE 2b). In the assessments made at different times, nectar production is continuous in both floral types of materials studied in both sites, differing from that reported by McGregor and Todd (1952), who registered a decreased production of this resource by male flowers in the afternoon.

The supply of floral resources at larger amounts by hermaphrodite flowers could make them more attractive to bees, thereby maximizing resource foraging. This production capacity could also be related to the size of the nectar chamber, which was deeper and could accumulate larger volumes of nectar and protect it. In studies on Cantaloupe melon, differences in the volume of nectar were recorded between the floral types, which were attributed to interruption of the secretion of this resource by male flowers (MCGREGOR; TODD, 1952). Studies made with watermelon (Citrullus lanatus colothynthoides L. - Cucurbitaceae) also verified the highest production of this floral resource by female than by male flowers, indicating that this may be a pattern for cucurbits (TAHA; BAYOUMI, 2009).

The comparison between hybrids in the study sites found significant differences in nectar volume only for hermaphrodite flowers, between hybrids 10/00 and Mandacaru $(\mathrm{P}<0.05)$, in Petrolina $(\mathrm{PE}) /$ Juazeiro (BA), and between Goldex and McLaren, in Mossoró $(\mathrm{RN})(\mathrm{P}<0.05)$. In relation to the concentration of nectar, although the evaluations have been made in both sites, only from the hybrids of Petrolina (PE)/Juazeiro (BA) it was possible to collect sufficient volume for analysis. According to Figure 2c, there were no differences between male and hermaphrodite flowers of the hybrids or between hybrids. These results indicate that differences in nectar volume between the floral types of the same hybrid as well as between different hybrids could influence the plant-pollinator relationship.

Visitation: Observations of the visitation pattern of A. mellifera were made in commercial areas in the region of Petrolina $(\mathrm{PE}) / \mathrm{Juazeiro}-\mathrm{BA}\left(\mathrm{F}_{1}\right)$ and Mossoró $\left(\mathrm{F}_{2}\right)$, in cultivation with simultaneous flowering of three types of melon, significant differences were detected in the frequency of visits among the hybrids $\left(\mathrm{F}_{1}=51.938 ; \mathrm{df}=2,493 ; \mathrm{P}<\right.$ $\left.0.01 ; \mathrm{F}_{2}=39.752 ; \mathrm{df}=1,869 ; \mathrm{P}<0.01\right)$, floral type $\left(F_{1}=27.436 ; \mathrm{df}=2,490 ; \mathrm{P}<0.01 ; \mathrm{F}_{2}=21.578 ; \mathrm{df}=\right.$ $1,866 ; \mathrm{P}<0.01)$ and foraged resource $\left(\mathrm{F}_{1}=60.017\right.$, $\mathrm{df}=2,490 ; \mathrm{P}<0.01, \mathrm{~F}_{2}=44.845$, df $=1,866 ; \mathrm{P}$ $<0.01)$. In the region of Petrolina $(\mathrm{PE}) /$ Juazeiro (BA), we registered $1,903,4,227$ and 1,868 visits of the honeybee, respectively, to hybrids of Yellow melon - 10/00, Piel de Sapo melon - Sancho and Cantaloupe - Florentino, revealing that the hybrid Sancho received about two times more visits than the others. In Mossoró, there was a total of 1,453, 589 and 1,912 visits of A. mellifera to the hybrids Yellow - Iracema, Galia - McLaren and Cantaloupe - Florentino and in this case, the flowers of the latter hybrid received more visits than the others.

Examining the number of visits per floral type, in the first study site (FIGURE 3a), the flowers of the hybrid Sancho were much more visited in both hermaphrodite $\left(\chi^{2}=519.998 ; \mathrm{df}=1, \mathrm{P}<0.0001\right)$ and male $\left(\chi^{2}=924.185, \mathrm{df}=1, \mathrm{P}<0.0001\right)$ flowers, thus evidencing that the flowers of this type of melon are more attractive to A. mellifera. In Mossoró (FIGURE $3 \mathrm{c})$, flowers of the melon Cantaloupe-Florentino were the most visited, both for hermaphrodite $\left(\chi^{2}=\right.$ 297.184; $\mathrm{df}=1, \mathrm{P}<0.0001)$ and male flowers $\left(\chi^{2}=\right.$ 410.968; $\mathrm{df}=1, \mathrm{P}<0.0001)$, indicating that, at this site, the flowers of this type of melon would also be more attractive to bees.

Regarding the floral resource foraged during bee visits (FIGURES $3 \mathrm{~b}$ and d), in hybrids investigated in the two sites studied, the frequency of visits for nectar collection was higher than for pollen collection, corroborating the observations made by Siqueira et al. (2011) and Kiill et al. (2012).

Comparing the frequency of visits between floral types of the same hybrid in relation to resource foraged, there was no difference only for pollen collection between male and hermaphrodite flowers of the hybrid Piel de Sapo-Sancho $\left(\chi^{2}=7.373 ; \mathrm{df}=1\right.$, $\mathrm{P}<0.0001$ ), in the region of Petrolina (PE)/Juazeiro (BA) and, between the floral types of Yellow-Iracema $\left(\chi^{2}=8.316 ; \mathrm{df}=1, \mathrm{P}<0.0001\right)$ and Galia-McLaren $\left(\chi^{2}=2.472 ; \mathrm{df}=1, \mathrm{P}<0.0001\right)$, in Mossoró ( $\left.\mathrm{RN}\right)$.

When compared the frequency of visits among hybrids, per floral type and foraged resource 
(FIGURES $3 \mathrm{c}$ and $\mathrm{d}$ ), the values were significant $\left(\chi^{2}\right.$ $>90 ; \mathrm{df}=2 ; \mathrm{P}<0.0001)$ for both nectar collection and for pollen collection, in hermaphrodite and male flowers, in both study sites. This result indicates that competition may occur between these types of melon under simultaneous cultivation in the attraction of pollinators.

Comparing the floral characteristics and frequency of visits, in the region of Petrolina (PE)/ Juazeiro (BA), the hybrid Piel de Sapo-Sancho showed the largest diameter of corolla, the greatest height of nectar chamber and flowers most visited. This indicates that, in addition to the visual attractiveness, flowers of this hybrid would be able to accumulate more nectar, and that this production could be stimulated throughout the day, given the highest visitation. In this study, flowers of this hybrid produced no expressive volume of nectar, which can be attributed to the methodology used. In Mossoró, the hybrid Cantaloupe-Florentino received the highest number of visits, although its flowers did not differ in relation to the assessed morphological characteristics.
In this sense, differences in floral morphology and nectar production found between the floral types justify the higher frequency of visits of $A$. mellifera to hermaphrodite flowers of melon hybrids studied in the two sites, according to the literature (SIQUEIRA et al., 2011; KIILL et al., 2012). But these differences were not sufficient to explain the variation in the frequency of visits to the same floral type among different hybrids, indicating that, besides the characteristics evaluated here, others could influence the attractiveness of the flower to the pollinator. Accordingly, many factors can influence pollination in an agricultural area, including the attractiveness of flowers of the crop to pollinators, the frequency of each type of flower, the density of flowers, among others (MAUÉS, 2014). Furthermore, the visitation pattern may also be affected by characteristics inherent to the behavior of the bee (PINHEIRO et al., 2014)

Importantly, the floral characteristics of melon hybrids should be valued in breeding programs, since they influence the plant-pollinator relationship and hence the productivity of the crop. Thereby, comparative studies of productivity of hybrids grown alone or in simultaneous crops should be further conducted to compute this influence.

TABLE 1- Types, hybrids and cultivars of melon studied in commercial and experimental areas in centers of Petrolina (PE)/Juazeiro (BA) and Mossoró (RN).

\begin{tabular}{lcc}
\hline \multicolumn{1}{c}{ Melon studied } & Petrolina-PE/Juazeiro-BA & Mossoró-RN \\
\hline Yellow 10/00 & $\mathrm{X}$ & \\
Yellow Mandacaru & $\mathrm{X}$ & \\
Yellow Goldex & & $\mathrm{X}$ \\
Yellow Iracema & $\mathrm{X}$ \\
Cantaloupe Florentino & & $\mathrm{X}$ \\
Galia McLaren & $\mathrm{X}$ & $\mathrm{X}$ \\
Piel de Sapo- Sancho & & \\
\hline
\end{tabular}




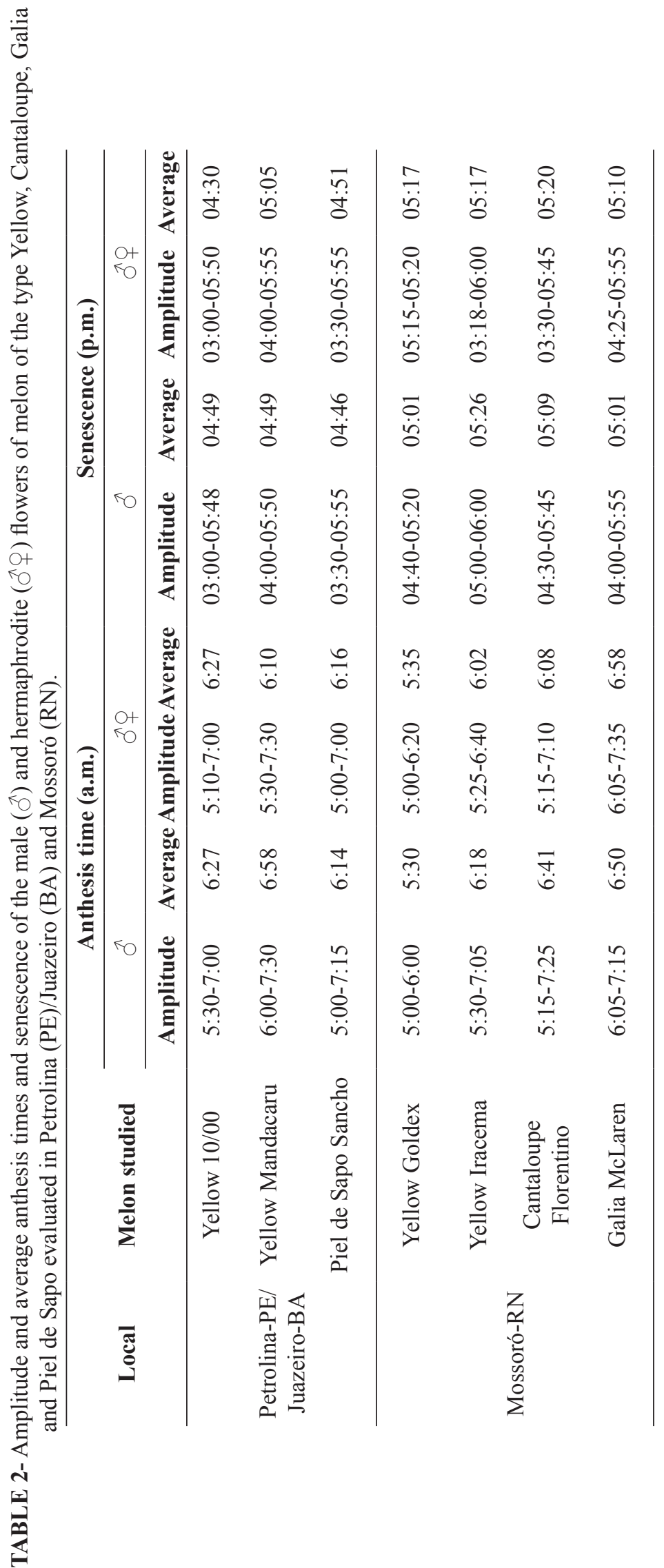



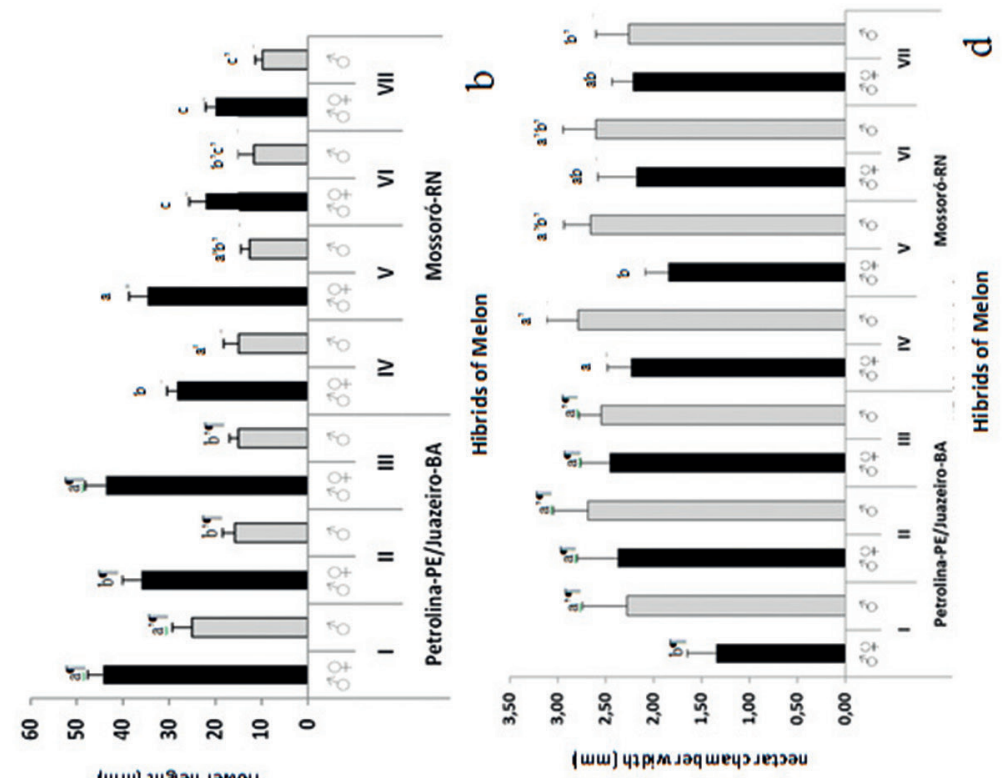

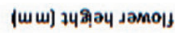

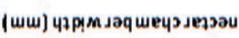
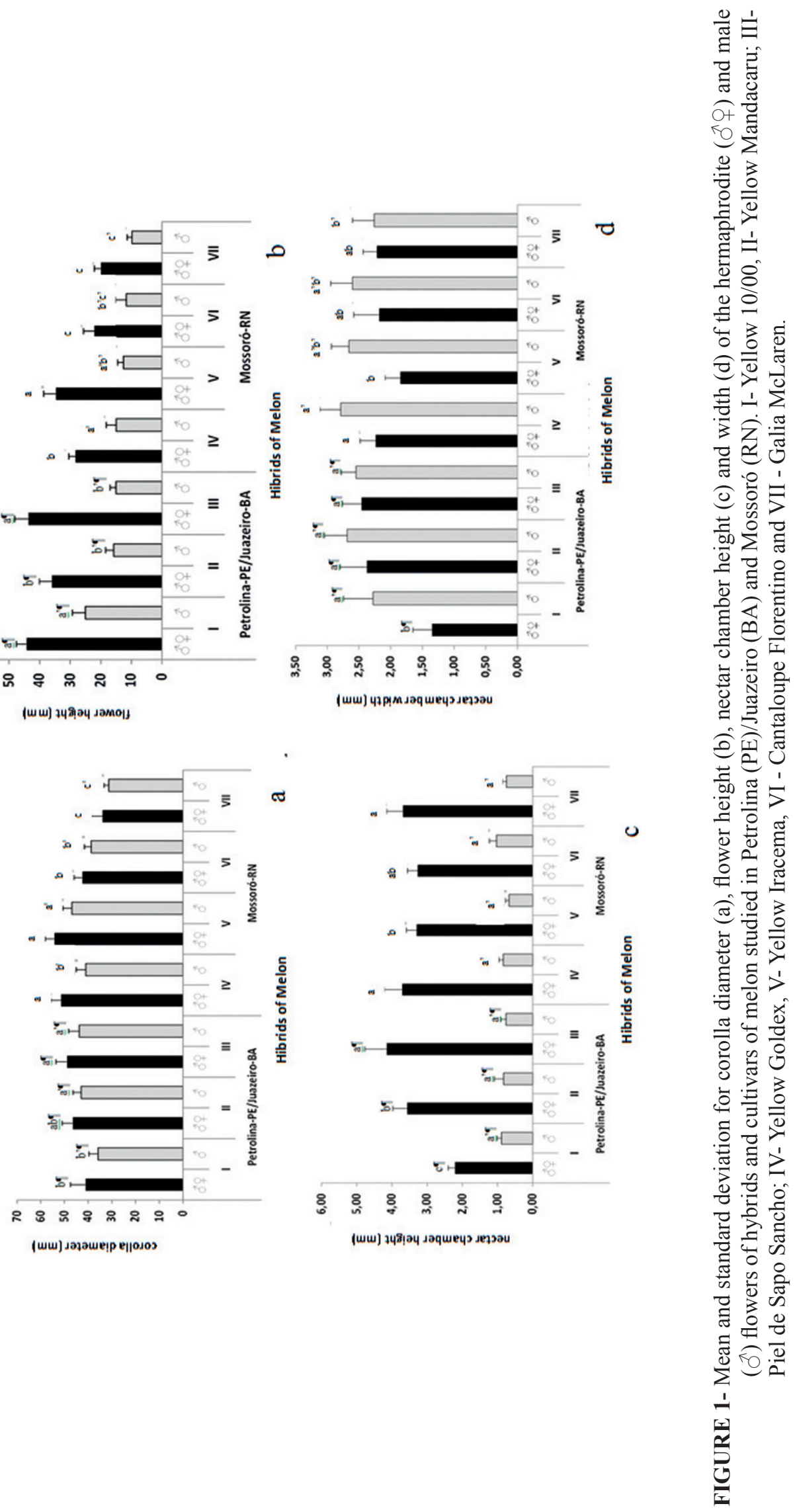

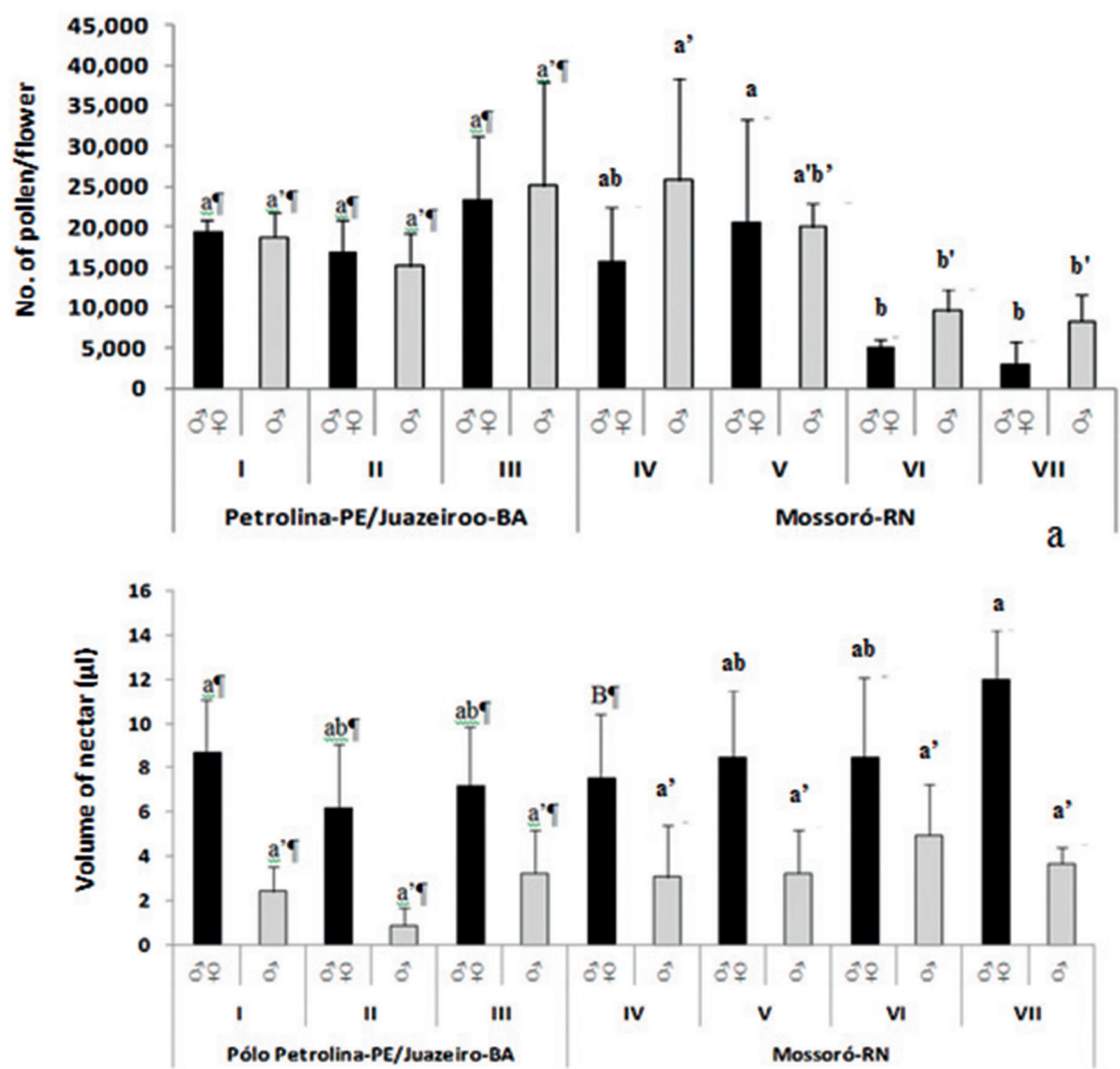

$\mathrm{b}$

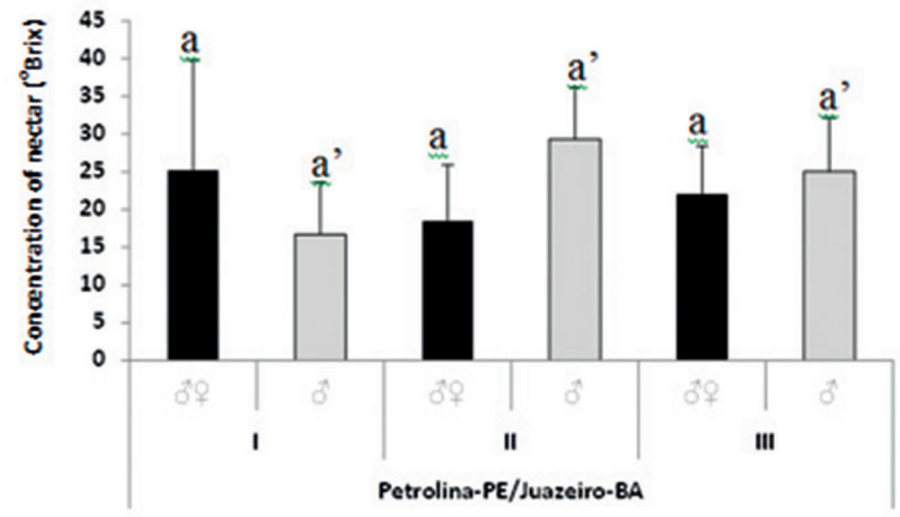

C

FIGURE 2- Mean and standard deviation for the number of pollen grains per flower (a), volume (b) and

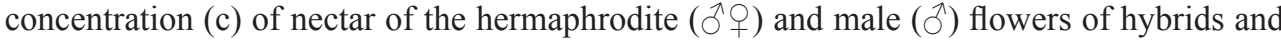
cultivars of melon studied in Petrolina (PE)/Juazeiro (BA) and Mossoró (RN). I- Yellow 10/00, II- Yellow Mandacaru; III- Piel de Sapo Sancho; IV- Yellow Goldex, V- Yellow Iracema, VI - Cantaloupe Florentino and VII - Galia McLaren. 

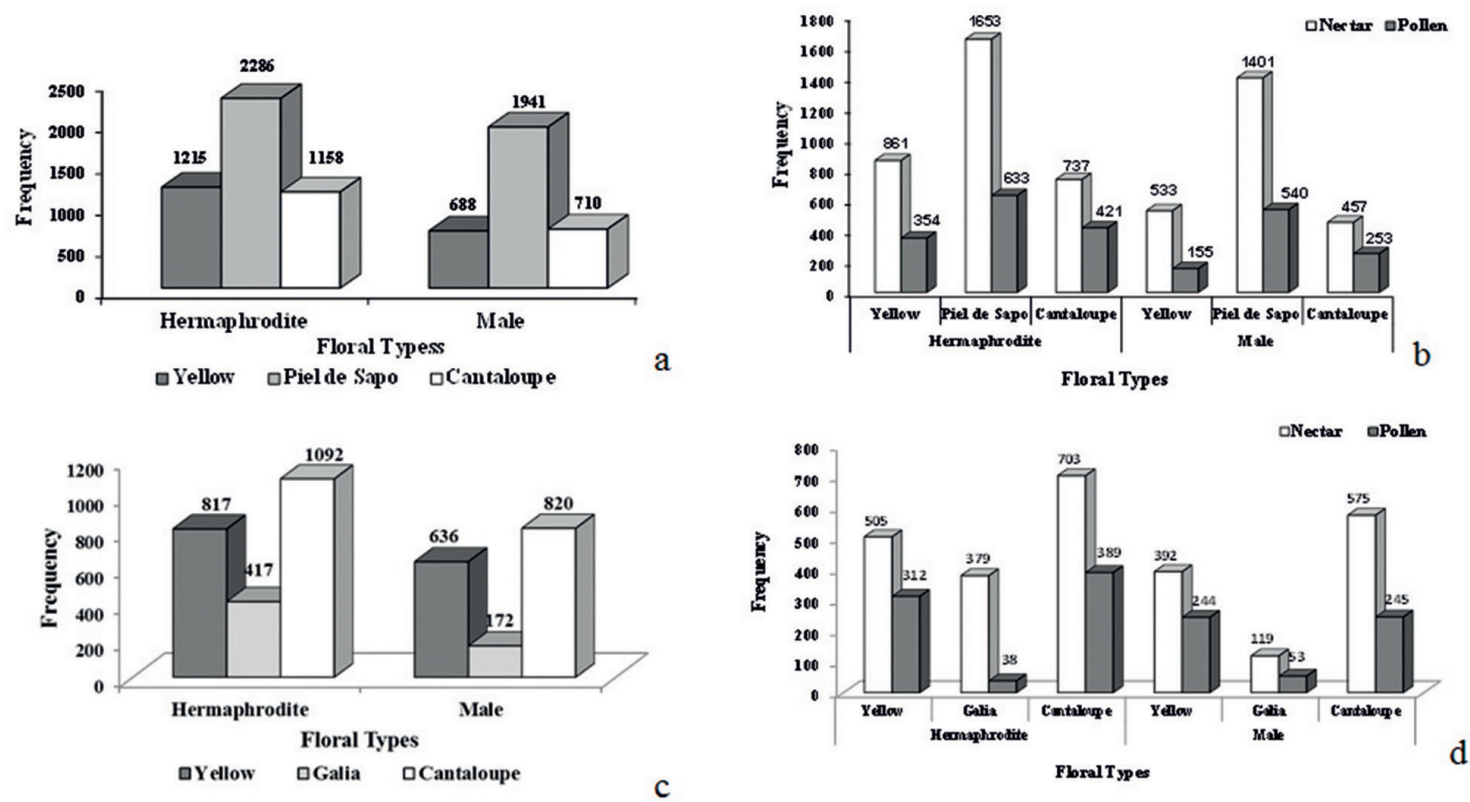

FIGURE 3 - Frequency of visits of Apis mellifera per floral type (a-c) and per resource (b and d) of hybrids and cultivars of melon evaluated in Petrolina (PE)/Juazeiro (BA) (b) and Mossoró (RN) (c and d).

\section{CONCLUSIONS}

In the region of Petrolina (PE)/Juazeiro (BA), flowers of the hybrid Piel de Sapo showed the largest diameter of the corolla and greater availability of pollen in both floral types, as well as the largest nectar chamber in hermaphrodite flowers. In Mossoró (RN), flowers of Cantaloupe exhibited the largest diameter of the corolla and width of the nectar chamber in both floral types as well as greater height and nectar volume in male flowers. These characteristics could explain the higher visitation to flowers of these hybrids in the locations studied.

\section{ACKNOWLEDGEMENTS}

We thank the Conselho Nacional de Desenvolvimento Científico e Tecnológico (CNPq), for financially supporting the project "Evaluation of the efficiency of pollination services in the increment of melon (Cucumis melon L. Cucurbitaceae) production in the Brazilian semiarid" (proc. $556055 / 2009-8)$.

\section{REFERENCES}

ABREU, T.B.; NUNES, G.H.S.; DANTAS, M.S.M.; COSTA FILHO, J.H.; COSTA, G.G.; ARAGÃO, F.A.S. Fenologia floral, viabilidade do grão de pólen e receptividade do estigma do meloeiro. Proceedings of the Interamerican Society for Tropical Horticulture, Vitória da Conquista, v.52, p.43-46, 2008.

DAFNI,A.; KEVAN, P.G.; HUSBAND, B.C. Pratical pollination biology. Cambridge: Environquest, 2005. $590 \mathrm{p}$.

DELAPLANE, K.S.; MAYER, D.F. Crop pollination by bee. Oxon: CABI Publishing, 2005. 344p.

DJÈ, Y.; KOUONON, L.C.; ZORO BI, I.A.; GNAMIEN, G.Y.; BAUDOIN, J.P. Etude des caractéristiques botaniques, agronomiques et de la biologie florale du melon africain (Cucumis melo L. subsp. agrestis Naudin, Cucurbitaceae). Biotechnologie, Agronomie, Société et Environnement, Gembloux, v.10, n.2, p.109-119, 2006. 
DORADO, J.; VÁZQUEZ, D.P. The diversitystability relationship in floral production. Oikos, Copenhagen, v.123, n.9, p.1137-1143, 2014.

FAO. Organização das Nações Unidas para a Agricultura e a Alimentação. Estatísticas. Disponível em: $\leq$ http://faostat3.fao.org $>$. Acesso em: 8 nov. 2013.

GARG, N.; SIDHU, A.S.; CHEEMA, D.S. Systematics of genus Cucumis: a review of literature. Haryana Journal of Horticulture Science, Ann Arbor, v.36, n.1-2, p.192-197, 2007.

GIANNINI, T.C.; BOFF, S.; CORDEIRO, G.D.; CARTOLANO JR., E.A.; VEIGA, A.K.; IMPERATRIZ-FONSECA, V.L.; SARAIVA, A.M. Crop pollinators in Brazil: a review of reported interactions. Apidologie, Versailles, v.46, n.2, p.209223, 2015.

HEIN, L. The economic value of the pollination service, a review across scales. The open Ecology Journal, Wageningen, v.2, p.74-82, 2009.

HOZ, J.C.T. Visita de abejas (Apis mellifera, Hymenoptera: Apoidea) a flores de melón Cucumis melo (Cucurbitaceae) en Panamá. Revista de Biología Tropical, San José, v.55, n.2, p.677-680, 2007.

KEARNS, C.A.; INOUYE, D.W. Techniques for pollination biologists. Niwot: University Press of Colorado, 1993. 559p.

KIILL, L.H.P.; COELHO, M. de S.; SIQUEIRA, K.M. de M.; COSTA, N.D. Avaliação do padrão de visitação de Apis mellifera em três cultivares de meloeiro, em Petrolina-PE, Brasil. Revista Brasileira de Fruticultura, Jaboticabal, v.33, p.455460, 2011. Número especial.

KIILL, L.H.P.; COELHO, M.de S.; SIQUEIRA, K.M.M.; RIBEIRO, M. de F.; COSTA, N.D.; FERNANDES, N.de S.; SILVA, T.A. Relationship of floral morphology and biology of yellow melon hybrids with the attractiveness of pollinators. Magistra, Cruz das Almas, v.24, p.143-149, 2012. Número Especial.
KLEIN, A.M.; VAISSIÈRE, B.E.; CANE, J.H.; DEWENTER, I.S.; CUNNINGHAM, S.A.; KREMER, C.; TSHARNTKE, T. Importance of pollinators in changing landscapes for world crops. Proceedings Royal Society B. Biological Sciences, Londres, v.274, p.303-313, 2007.

KOUONOM, L.C.; JACQUEMART, A.F.; ZORO BI, A.I.; BERTIN, P.; BAUDOIN, J.P.; DJE, Y. Reproductive biology of the andromonoecious Cucumis melo subsp. agrestis (Cucurbitaceae). Annals of Botany, Oxford, v.104, n.6, p.1129-1129, 2009.

MAUÉS, M.M. Economia e Polinização: custos, ameaças e alternativas. In: RECH, A.R.; AGOSTINI, K.; OLIVEIRA, P.E.; MACHADO, I.C. (Org.). Biologia da polinização. Rio de Janeiro: Ed. Projeto Cultural, 2014. p.461-481.

MCGREGOR, S.E.; TODD, F.E. Cantaloupe production with honey bees. Journal of Economic Entomology, Menasha, v.45, n.1, p.43-7, 1952.

PINHEIRO, M.; GAGLIANONE, M.C.; NUNES, C.E.P.; SIGRIST, M.R.; SANTOS, I.A. Polinização por abelhas IN: RECH, A.R.; AGOSTINI, K.; OLIVEIRA, P.E.; MACHADO, I.C. (Org.). Biologia da polinização. Rio de Janeiro: Ed. Projeto Cultural, 2014. p.205-233.

RECH, A.R.; AVILA JR, R.S.; SCHLINDWEIN, C. Síndromes de polinização: especialização e generalização. In: RECH, A.R.; AGOSTINI, K.; OLIVEIRA, P.E.; MACHADO, I.C. (Org.). Biologia da polinização. Rio de Janeiro: Ed. Projeto Cultural, 2014. p.171-182.

SIQUEIRA, K.M.M. de; KIILL, L.H.P.; GAMA, D.R. da S.; ARAÚJO, D.C. DOS S.; COELHO, M. de S. Comparação do padrão de floração e de visitação do meloeiro do tipo amarelo em Juazeiro-BA. Revista Brasileira de Fruticultura, Jaboticabal, v.E, p.473-478, 2011. Volume Especial

SOUSA, R.M.; AGUIAR, O.S.; FREITAS, B.M.; SILVEIRA NETO, A.A.; PEREIRA, T.F.C. Requerimentos de polinização do meloeiro (Cucumis melo L.) no município de Acaraú - CE - Brasil. Revista Caatinga, Mossoró, v.22, n.1, p.238-242. 2009. 
SOUSA, R.M. de; AGUIAR, O de S.; FREITAS, B.M.; MARACAJÁ, P.B.; ANDRADE, C.B.C.M. de. Grazing behavior of africanized honey bees (Apis mellifera L.) in flowers of yellow melon (Cucumis melo L.). Revista Verde, Mossoró, v.7, n.1., p.233238. 2012.

SOUZA, D.L.; EVANGELISTA-RODRIGUES, A.; RIBEIRO, M.N.; PADILLAÁLVAREZ, F.; FARIAS, E.S.L.; PEREIRA, W.E. Análises morfométricas entre Apis mellifera da mesorregião do sertão paraibano. Archivos de Zootecnia, Córdoba, v.58, n.221, p.65-71, 2009.
STATSOFT. Statistica (data analysis software system). version 7. 2004. Disponível em: $<\underline{w w w}$. statsoft.com>.

TAHA, E.A.; BAYOUMI, Y.A. The value of honey bees (Apis mellifera, L.) as pollinators of summer seed watermelon (Citrullus lanatus colothynthoides L.) in Egypt. Acta Biologica Szegediensis, Szeged, v.53, n.1, p.33-37, 2009.

TSCHOEKE, P.H.; OLIVEIRA, E.E.; DALCIN, M.S.; SILVEIRA-TSCHOEKE, M.C.A.C.; SANTOS, G.R. Diversity and flower-visiting rates of bee species as potential pollinators of melon (Cucumis melo L.) in the Brazilian Cerrado. Scientia Horticulturae, Amsterdam, v 186, p.207-216, 2015. 